Semkiv, M.V., Ternavska, O.T., Dmytruk, K.V., and Sibirny, A.A.

Institute of Cell Biology, the NAS of Ukraine,

14/16, Drahomanov St., Lviv, 79005, Ukraine,

+380 3226 12108, +380 3226 12148, sibirny@cellbiol.lviv.ua

\title{
EFFECT OF TREHALOSE AND GLYCEROL ON THE RESISTANCE OF RECOMBINANT SACCHAROMYCES CEREVISIAE STRAINS TO DESICCATION, FREEZE-THAW AND OSMOTIC STRESSES
}

Introduction. Baker's yeast Saccharomyces cerevisiae has been used for manufacturing bakery products, food and feed supplements, alcoholic fermentation etc. In biotechnological processes, yeast cells are exposed to stress factors ( high concentration of sugars and ethanol, high temperature, desiccation or freezing etc.), which negatively affects their viability. Yeasts possess certain stress protection systems, including increased accumulation of disaccharide trehalose and glycerol synthesis.

Problem Statement. The strengthening of yeast protective systems by increasing glycerol or trehalose concentrations can help to get increased stress robustness of the $S$. cerevisiae strains.

Purpose. To construct the recombinant strains of $S$. cerevisiae with increased trehalose accumulation or glycerol production and to estimate the obtained recombinant strains resistance to a range of stress factors.

Materials and Methods. S. cerevisiae transformation has been performed using Li-Ac-PEG method. Alcoholic fermentation has been carried out at a temperature of $30{ }^{\circ} \mathrm{C}$ with stirring at a rate of $120 \mathrm{rpm}$.

Results. The recombinant strains of S. cerevisiae with enhanced glycerol production (up to $19 \mathrm{~g} / \mathrm{L}$ ) have been constructed based on BY4742. The industrial ethanol-producing strain Y-563 has been used as parental one for construction of recombinant strains with up to 3.3-fold increase in the intracellular trehalose level. The resistance of obtained recombinant strains to different stress factors has been evaluated. BY/TPI25/gpd1gpp2f/fps1 strain with the highest glycerol production has been established to have the highest osmotolerance. The BY/TPI25/gpd1gpp2f, 563/TSL1, 563/TPS1/2 and 563/TPS1/2/TSL1 strains have shown higher viability after freeze-thaw as compared with the corresponding parental strains, but not higher resistance to desiccation. The recombinant strain 563/TPS1/2/TSL1 with a high trehalose content have been established to have higher activity during fermentation of sugar in sweet dough and to longer keep stable at $35{ }^{\circ} \mathrm{C}$ as compared with the initial strain Y-563.

Conclusions. Constructed recombinant strains of S. cerevisiae with higher osmotolerance or freeze-thaw resistance can be implemented in industrial processes accompanied with these types of stresses. Baker's yeast made of high trehalose-containing biomass will have prolonged shelf life.

Key words: baker's yeasts, trehalose, glycerol, freeze-thaw, desiccation, and osmotolerance.

\section{INTRODUCTION}

Baker's yeast Saccharomyces cerevisiae is used in bread baking, manufacture of soft and strong

(C) SEMKIV, M.V., TERNAVSKA, O.T., DMYTRUK, K.V., and SIBIRNY, A.A., 2018 alcoholic beverages, production of commercial ethanol and fuel, preparation of food/feed supplements (inactivated flaked yeast, yeast autolysates, yeast hydrolysates, yeast extracts, vitamin supplements, etc.). To be used in these industrial processes, yeast cells have to efficiently resist 

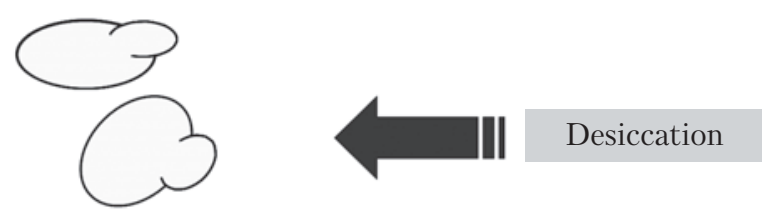

Active dry yeast

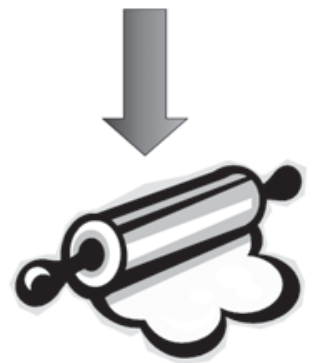

Sweet dough

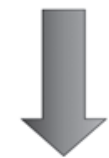

Frozen-dough baking
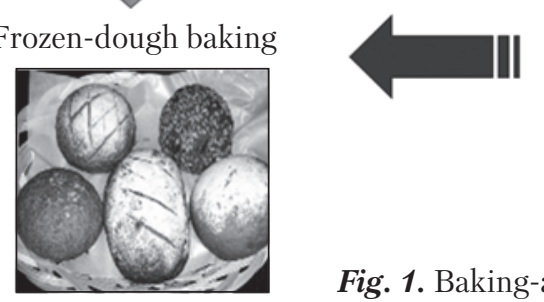

Freeze-thaw

Fig. 1. Baking-associated stresses

various external stresses. This research deals with some stress factors to which yeast cells are exposed during the production of different yeast preparations for baking (compressed yeast, crumbled yeast, liquid yeast, active dry yeast etc.) and dough fermentation. Such baking-associated stresses include, for instance, desiccation, freeze-thaw, and osmotic stress (Fig. 1).

Baker's yeast preparations made mainly of S. cerevisiae biomass are indispensable element of bread baking (Randez-Gil, Sanz, \& Prieto, 1999). Annually, about 2 million ton baker's yeast is produced worldwide (Attfield, 1997). Baker's yeast is produced as suspension that contains about $20 \%$ of dry cells biomass; as compressed yeast that contains $30 \%$ of dry cells biomass; and dry yeast with a moisture content of only $5 \%$. In Ukraine, mainly compressed yeast or yeast suspension is used for baking. Dry yeast is also prepared in small amount or imported from other count- ries and is used for bread baking in small bakeries or households.

The yeast suspensions should be stored and transported at a temperature of $4{ }^{\circ} \mathrm{C}$. They have a limited shelf life and as it expires undergo cell autolysis. For such yeast, extension of shelf life is very important. The yeast cells used for dried yeast preparation must be resistant to desiccation and retain a high fermentation activity after rehydration. If dough recipe requires a lot of sugar (the so called sweet dough), the yeast cells are exposed to high osmotic pressure. This leads to water loss and shrinkage of cells, so yeast cells have to be able to retain water and in such way to resist osmotic stress. When bread is baked from frozen dough (which often happens), yeast cells have to keep viable and active after freeze-thaw procedure. Bread baking and other industrial processes involving $S$. cerevisiae will massively benefit from obtaining robust $S$. cerevisiae strains resistant to all of the mentioned stresses.

These different stress factors are considered to induce oxidative stress accompanied by the formation of reactive oxygen species (ROS) due to protein denaturation and destruction of mitochondrial and electron transport chain components (Ando, Nakamura, Murata, Takagi, \& Shima, 2007). In the presence of high amounts of ROS the yeast cells fermentation activity is severely suppressed, which impairs their performance in the industrial processes.

The yeast cells have multiple mechanisms of adaptation to stress factors, e.g. synthesis of heat-shock proteins, compounds with antioxidant properties and compatible solutes, modification of plasma membrane components and suppression of translation, etc. In this research, the role of trehalose and glycerol as stress-protectors is studied.

Disaccharide trehalose is one of the most comprehensively studied factors of cell protection in unfavorable environments caused by desiccation, freezing, high temperature, ethanol, and osmotic stresses (Crowe, 2007). Trehalose protects membrane structures by decreasing temperature of 


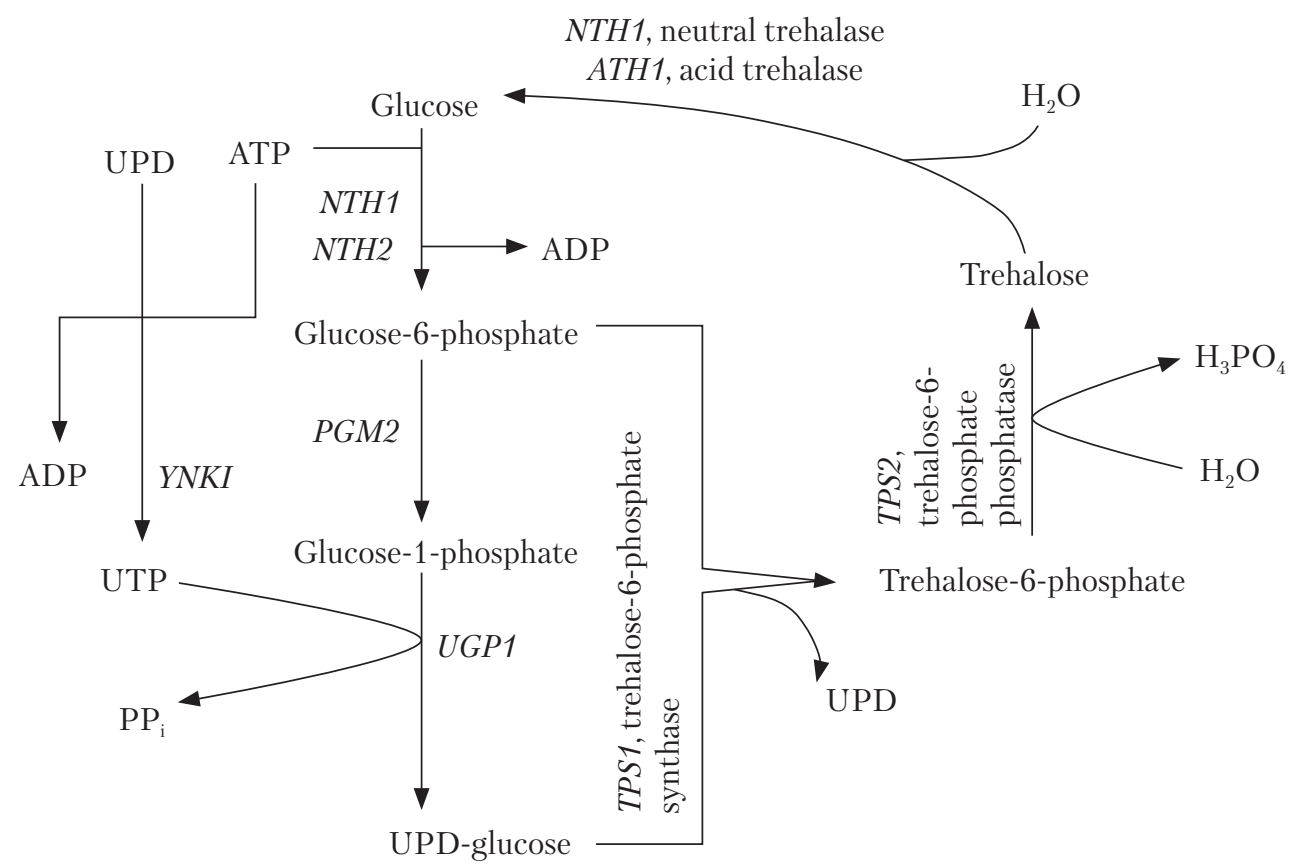

Fig. 2. Trehalose metabolism in S. cerevisiae. HXK1, HXK2 - hexokinases; UGP1 - UDP-glucose pyrophosphorylase; PGM2 - phosphoglucomutase; YNK1 - nucleoside diphosphate kinase; NTH1 - neutral trehalase; ATH1 - acid trehalose; TPS1 - trehalose-6-phosphate synthase; TPS2 - trehalose-6-phosphate phosphatase

membrane lipids thawing, stabilizes the process of protein folding, and prevents proteins from aggregation (Tapia \& Koshland, 2014). The increased level of intracellular trehalose has been found to be necessary for yeast cells to survive after desiccation-rehydration (Tapia \& Koshland, 2014). It is known, that during alcoholic fermentation the yeast cells accumulate trehalose and its level can reach 15\% of dry cell mass (Francois \& Parrou, 2001). However, the most thoroughly studied function of trehalose is protection of cells against heat shock (Wiemken, 1990).

Trehalose metabolism in $S$. cerevisiae has been studied in detail and represents a precise balance between the substance synthesis and hydrolysis (Fig. 2) (Kim, Alizadeh, Harding, Hefner-Gravink, \& Klionsky, 1996). Trehalose synthesis is performed by big enzymatic complex that consists of trehalose-6-phosphate synthase encoded by TPS1 gene and trehalose-6-phosphate phosphatase encoded by TPS2 gene. Trehalose-6phosphate synthase catalyzes condensation between glucose-6-phospate and UDP-glucose to form trehalose-6-phosphate. Subsequently, trehalose-6-phosphate is converted into trehalose by the action of trehalose-6-phosphate phosphatase. Overexpression of, at least, one of these genes TPS1 - causes an increase in intracellular trehalose concentration and an enhanced heat tolerance of the corresponding recombinant $S$. cerevisiae strains. Trehalose hydrolysis is catalyzed by two isoenzymes: acid trehalase (encoded by ATH1 gene) and neutral trehalase (encoded by NTH1 gene) (Londesborough \& Varimo, 1984). Acid trehalase is necessary for $S$. cerevisiae growth in the medium with trehalose as a sole source of carbon and energy (Nwaka, Mechler, \& Holzer, 1996). The deletion of ATH1 gene in S. cerevisiae causes a more noticeable increase in cellular trehalose level, than that of NTH1 gene (Kim et al., 1996). It has been shown, that ath1 $\Delta$ strain of $S$. cerevisiae is more resistant to desiccation, lowtemperature incubation, ethanol, and osmotic stresses as compared with the homogenic strain (Kim et al., 1996). A decrease in acid trehalase activity in $S$. cerevisiae enhances its tolerance to 
ethanol and productivity of alcoholic fermentation (Jung \& Park, 2005).

So, the enhanced trehalose level ensures the resistance of yeast cells to high temperature, freeze-thaw stress, high osmotic pressure in the medium, high ethanol concentration etc. (Guo, Zhang, Ding, \& Shi, 2011). Recently, trehalose has been suggested to be very efficient in the medical treatment of some human diseases (Byun, Lee, \& Lee, 2017). Therefore, the prospects for obtaining trehalose-overproducing $S$. cerevisiae recombinant strains are very promising.

Sustainable water balance is an obligatory condition of cell existence. Rapid changes in environmental osmolarity and moisture content can be detrimental for the living cells, for example, increased osmolarity of the cellular environment causes water efflux from the cells and, as a result, their shrinkage. Universal strategy of cell survival in these conditions is a synthesis of compatible solutes to compensate for a moisture decrease (Yancey, Clark, Hand, Bowlus, \& Somero, 1982). Such molecules are compatible with intracellular processes and either replace water or/and revert the water concentration gradient and drive water back into cells. The most abundant compatible solutes in microorganisms are small uncharged molecules such as: (1) polyols (glycerol, arabitol, trehalose or sucrose); (2) amino acids (proline, glutamate or glutamine); and (3) ectoines, (ectoine or $\beta$-hydroxyectoine) (Grant, 2004). In the yeasts, glycerol is one of the most widespread compatible solute that ensures an acceptable cell turgor under high extracellular osmolarity (Blomberg \& Adler, 1992; Brown, 1978). For example, during the initial phase of alcoholic fermentation, $S$. cerevisiae cells accumulate an enhanced amount of glycerol in response to osmotic stress caused by a high sugar concentration in grape must. Also, S. cerevisiae produces a lot of glycerol while growing in the medium with a high salt ( $\mathrm{NaCl}$ ) concentration (Blomberg \& Adler, 1989). Adaptation of $S$. cerevisiae to hyper-osmotic stress is accomplished via increased glycerol accumulation and its retention inside the cells. The mu-

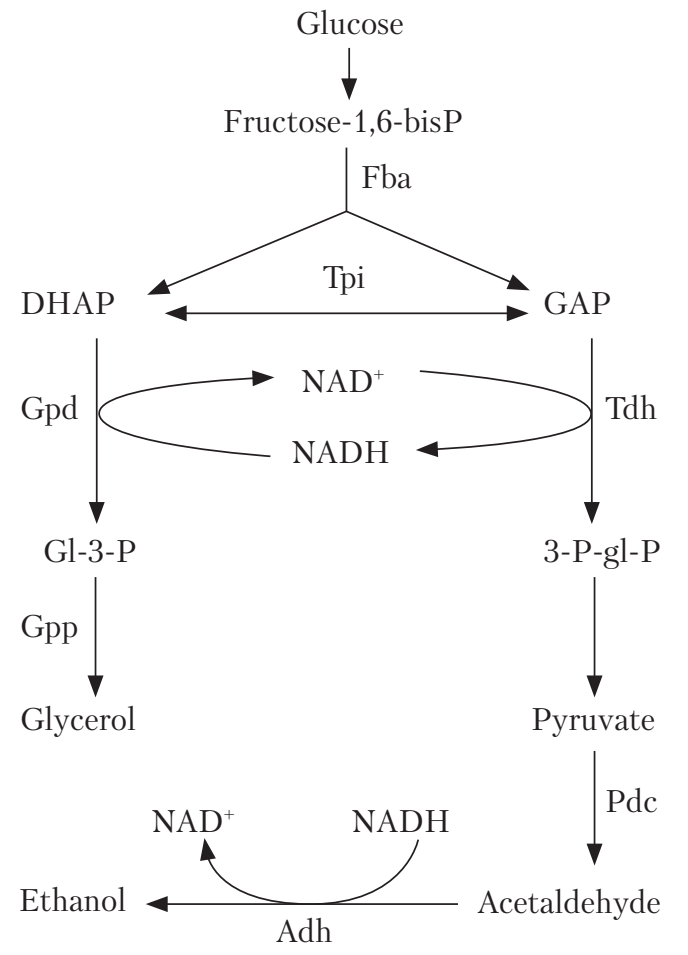

Fig. 3. Central metabolism and glycerol production by $S$. cerevisiae. DHAP, dihydroxyacetone phosphate; GAP, glyceraldehyde 3-phosphate; Gl-3-P, glycerol 3-phosphate; 3-P-gl-P, 1,3-bisphosphoglycerate; Fba, aldolase; Tpi, triose phosphate isomerase; Gpd, glycerol 3-phosphate dehydrogenase; Gpp, glycerol 3-phosphate phosphatase; Pdc, pyruvate decarboxylase; Adh, alcohol dehydrogenase

tants blocking the synthesis of glycerol (e.g. $g p d 1 \Delta g p d 2 \Delta)$ or causing the leakage of glycerol out of the cell (e.g. with hyperactive membrane channel Fps1), have an osmo-sensitive phenotype (Hohmann, 2002).

In $S$. cerevisiae, glycerol is synthesized from dihydroxyacetone phosphate (DHAP) in two consequential reactions catalyzed by cytosolic enzymes glycerol-3-phosohate dehydrogenase (Gpd) and glycerol-3-phosphate phosphatase (Gpp) (Fig. 3). DHAP can also be converted to glyceraldehyde-3-phosphate and vice versa under the action of triose phosphate isomerase (Tpi). The recombinant $S$. cerevisiae strain with TPI1 gene deletion produces high amounts of glycerol, but is unable to grow on the glucose as a sole carbon source (Overkamp et al., 2002). 
Cytosolic NAD ${ }^{+}$-depended Gpd catalyzes the DHAP reduction to glycerol-3-phosphate, which is accompanied by oxidation of NADH to $\mathrm{NAD}^{+}$. The Gpd activity determines the overall rate of glycerol synthesis in the cells (Remize, Barnavon, \& Dequin, 2001). In S. cerevisiae, Gpd is encoded by two isogenes: osmotically induced GPD1 gene (Albertyn, Hohmann, Thevelein, \& Prior, 1994; Larsson, Ansell, Eriksson, \& Adler, 1993) and GPD2 gene which translation is activated during cell growth in anaerobic conditions (Eriksson, Andre, Ansell, Blomberg, \& Adler, 1995; Larsson et al., 1993). During osmotic stress, the activity of Gpd1 isoform is also regulated on posttranslational level by dephosphorylation (Lee, Jeschke, Roelants, Thorner, \& Turk, 2012; Oliveira et al., 2012).

Like for Gpd, two isoforms of Gpp have been identified: the first one that is encoded by GPP1 gene is induced by a shift to anaerobic conditions (Pahlman, Granath, Ansell, Hohmann, \& Adler, 2001) and the second one that is encoded by GPP2 gene is activated during hyperosmotic stress (Norbeck, Pahlman, Akhtar, Blomberg, \& Adler, 1996; Pahlman et al., 2001). The evolutionary engineering of bicistronic artificial operon containing the yeast GPD1 and GPP2 genes in a heterologous system of Escherichia coli has resulted in obtaining GPD1-GPP2 fused gene (Meynial Salles, Forchhammer, Croux, Girbal, \& Soucaille, 2007). The product of this gene has both the catalytic sites of glycerol-3-phosphate dehydrogenase and glycerol-3-phosphate phosphatase and is able to convert DHAP into glycerol faster than separated glycerol-3-phosphate dehydrogenase and glycerol-3-phosphate phosphatase, which is likely explained by substrate channeling between the two active sites.

In $S$. cerevisiae, glycerol is exported from cells through the membrane channel formed with the protein Fps1 (Luyten et al., 1995). If the yeast cells are exposed to a high osmotic pressure, the channel would be shut down and the synthesized glycerol would be retained inside the cells (Luyten et al., 1995; Tamas et al., 1999). In anaerobic conditions, the expression level of FPS1 gene is higher, while in aerobic conditions, the transporter is needed to remove excessive glycerol (ter Linde et al., 1999). Fps1 protein has long $\mathrm{N}$ - and C-terminal domains that are necessary to shut down the channel. The Fps1 modified protein that lacks $\mathrm{N}$ - or $\mathrm{C}$-terminal domain becomes constantly open and exporting glycerol into cultivation medium (Ahmadpour, Geijer, Tamas, Lindkvist-Petersson, \& Hohmann, 2014). It is an interest fact that such intricate mechanism of Fps1 protein opening and closing occurs only in the yeasts closely related to $S$. cerevisiae (Pettersson, Filipsson, Becit, Brive, \& Hohmann, 2005). Supposedly it is the way to adapt itself to quickly changing environment osmotic pressure. To conclude, an increase in intracellular glycerol concentration in $S$. cerevisiae improves its resistance to osmotic stress. So the research aims at obtaining glycerol-overproducing recombinant strains to see how high osmotolerance they can have.

\section{MATERIALS AND METHODS}

In this research, the following microbial strains are used: S. cerevisiae: BY4742 (MAT $\alpha$, his3 31 , leu2 $\Delta 0$, lys2 $\Delta 0$, ura3 $\Delta 0$ ) - WT strain; BY/gpd1 recombinant strain with GPD1 gene overexpression; BY/gpd1gpp2f - recombinant strain with artificial fused GPD1-GPP2fus gene overexpression; BY/TPI25/gpd1gpp2f - recombinant strain with TPI1 promoter region shortened to $25 \mathrm{bp}$ and overexpression of GPD1-GPP2fus gene; BY/ TPI25/gpd1gpp2f/fps1m - recombinant strain with TPI1 promoter region shortened to $25 \mathrm{bp}$ and overexpression of genes GPD1-GPP2fus and FPS1m; Y-563 - a triploid hybrid yeast strain obtained by crossing the osmophilic ethanol-producing strain $S$. cerevisiae $\mathrm{SH}-1$ with the bakery strain $S$. cerevisiae $2-10$, which are able to effectively ferment raffinose; 563/TSL1 - recombinant strain with TSL1 gene overexpression, constructed based on Y-563 strain; 563/TPS1/2 recombinant strain with overexpression of the genes TPS1 and TPS2, constructed based on Y-563 strain; 563/TPS1/2/TSL1 - recombinant strain 
with overexpression of the genes TPS1, TPS2, and TSL1, constructed based on Y-563 strain. The Escherichia coli DH5 $\alpha$ strain ( 80dlacZ $\triangle \mathrm{M} 15$, recA1, endA1, gyrA96, thi-1, hsdR17 $\left(\mathrm{r}_{\mathrm{K}}{ }^{-}, \mathrm{m}_{\mathrm{K}}{ }^{+}\right)$, supE44, relA1, deoR, $\triangle($ lacZYA-argF $) \mathrm{U} 169)$ is used as a host for propagation of plasmids. Strain DH5a is grown at $37^{\circ} \mathrm{C}$ in LB medium. The transformed E. coli cells are maintained in a medium containing $100 \mathrm{mg} / \mathrm{L}$ ampicillin.

The $S$. cerevisiae strains are incubated at $30{ }^{\circ} \mathrm{C}$ and maintained in rich YPD $(10 \mathrm{~g} / \mathrm{L}$ yeast extract, $10 \mathrm{~g} / \mathrm{L}$ peptone and $20 \mathrm{~g} / \mathrm{L}$ glucose) or in mineral YNB (1.7 g/L yeast nitrogen base without amino acids, DIFCO, $5 \mathrm{~g} / \mathrm{L}$ ammonium sulfate, $20 \mathrm{~g} / \mathrm{L}$ glucose) media. Histidine (20 mg/L), leucine $(60 \mathrm{mg} / \mathrm{L})$, lysine $(20 \mathrm{mg} / \mathrm{L})$, or uracil (20 mg/L) are added when required. For ethanol fermentation, YNB medium with $100 \mathrm{~g} / \mathrm{L}$ glucose is used.

The $S$. cerevisiae transformation is performed using Li-Ac-PEG method (Kawai, Hashimoto, \& Murata, 2010). For selection of yeast transformants in YPD, $100 \mathrm{mg} / \mathrm{L}$ nourseothricin and $150 \mathrm{mg} / \mathrm{L}$ hygromycin B or $200 \mathrm{mg} / \mathrm{L}$ geneticin are added.

For alcoholic fermentation, the cells of studied yeast strains are grown in $50 \mathrm{~mL}$ YPD medium, in Erlenmeyer flasks (100 mL bottles), for 24 hours and then inoculated into $20 \mathrm{~mL} \mathrm{YNB}$ medium with $100 \mathrm{~g} / \mathrm{L}$ glucose, in $50 \mathrm{~mL}$ Erlenmeyer flasks. An initial biomass concentration of
0.9-1.15 g (dry weight)/L is used for fermentation. The fermentation is carried out at a temperature of $30{ }^{\circ} \mathrm{C}$ with a stirring rate of $120 \mathrm{rpm}$. The samples are taken daily.

The ethanol concentration in the fermentation broth is determined using alcohol oxidase/peroxidase-based Alcotest enzymatic kit (Gonchar, Maidan, Pavlishko, \& Sibirny, 2001). Alternatively, the concentrations of glycerol, glucose, and ethanol in the medium broth are analyzed by HPLC (PerkinElmer, Series 2000, USA) with an Aminex HPX-87H ion-exchange column (BioRad, Hercules, USA). A mobile phase of $4 \mathrm{mM}$ $\mathrm{H}_{2} \mathrm{SO}_{4}$ is used at a flow rate $0.6 \mathrm{~mL} / \mathrm{min}$ and at a column temperature of $35^{\circ} \mathrm{C}$. The intracellular trehalose level is assayed as described earlier (Ishchuk, Voronovsky, Abbas, \& Sibirny, 2009).

\section{RESULTS AND DISCUSSION}

In the previous research, a set of glycerol-overproducing $S$. cerevisiae recombinant strains was constructed (Semkiv, Dmytruk, Abbas, \& Sibirny, 2017): BY/gpd1; BY/gpd1gpp2f; BY/TPI25/gpd1gpp2f; BY/TPI25/gpd1gpp2f/fps1m (see $M a$ terials and Methods). These strains produce gradually increasing amounts of glycerol under semi-aerobic and anaerobic conditions (Fig. 4).

To construct the recombinant $S$. cerevisiae with increased intracellular trehalose level, a triploid hybrid yeast strain Y-563 is used. To overexpress

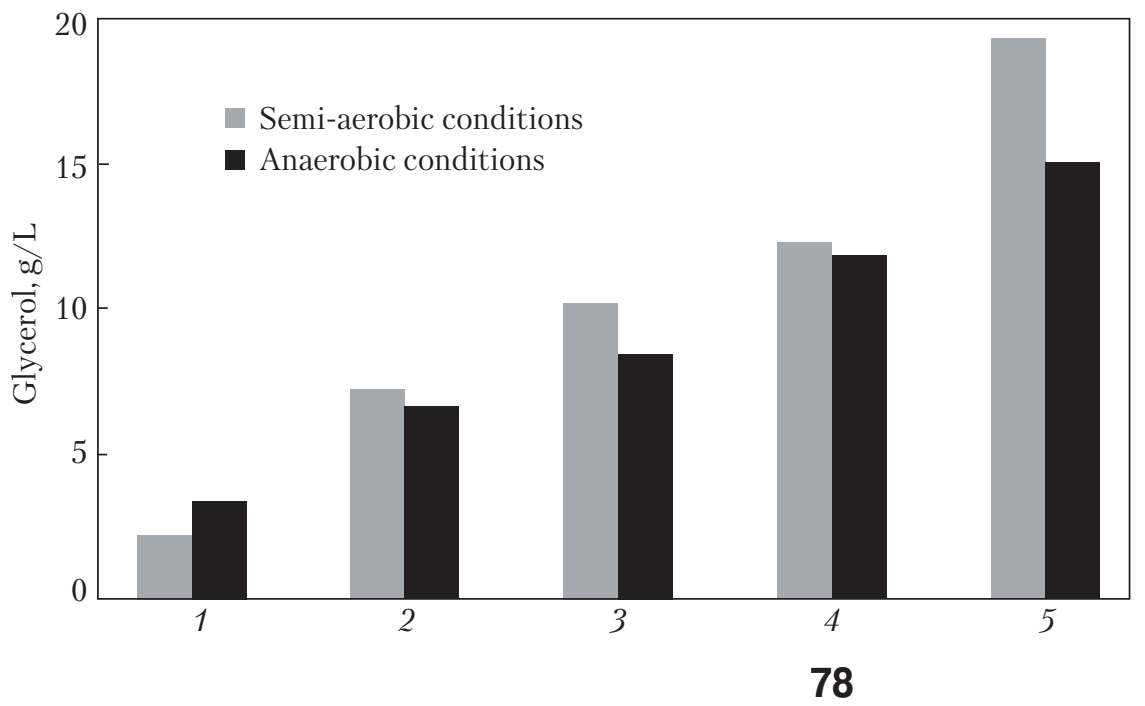

Fig. 4. Glycerol production (g/L) at the $48^{\text {th }}$ hour of fermentation in semiaerobic conditions (gray bars of the graph) or at the $72^{\text {nd }}$ hour of fermentation in anaerobic conditions (black bars of the graph). BY4742 (1) - WT strain; BY/gpd1 (2); BY/gpd1gpp2f (3); BY/TPI25/gpd1gpp2f (4); BY/ TPI25/gpd1gpp2f/fps1m (5) - studied recombinant strains 
the genes that encode trehalose-6-phosphate synthase and trehalose-6-phosphate phosphatase, there is constructed a vector for multicopy integration, in which ORF of TPS1 and TPS2 genes are placed under control of strong constitutive promoter of $A D H 1$ gene (coding for alcohol dehydrogenase) (Luzhetskyi, Semkiv, Dmytruk, \& Sibirny, 2015). The plasmid obtained is named pdelta-TPS1-TPS2 and used for transformation of Y-563 strain. One of the selected recombinant strains is named 563/TPS1/2 and used for the further analysis.

For overexpression of TSL1 gene, pdelta-TSL1 vector is constructed (Luzhetskyi et al., 2015) that contains ORF of the gene under the control of $A D H 1$ promoter and $h p h N T 1$ selection marker gene conferring resistance to hygromycin $\mathrm{B}$. The plasmid obtained is linearized with AhdI restriction endonuclease and used for transformation of $S$. cerevisiae strains Y-563 and 563/TPS1/2. Among the selected transformants, a strain with TSL1 gene overexpression and a strain with TPS1, TPS2, and TSL1 genes overexpression are chosen and named 563/TSL1 and 563/TPS1/2/TSL1, respectively. The intracellular trehalose content in the recombinant strain $563 / \mathrm{TPS} 1 / 2 / \mathrm{TSL} 1$ has shown a 3.3-fold increase as compared with the initial strain Y-563 (Fig. 5).

Alcoholic fermentation with strains Y-563 and $563 / \mathrm{TPS} 1 / 2 / \mathrm{TSL} 1$ is performed in $1 \mathrm{~L}$ fermenter in YPD medium at a stirring rate of $200 \mathrm{rpm}$, a temperature of $40{ }^{\circ} \mathrm{C}$, and $\mathrm{pH}=5.5$. Glucose in the medium is completely consumed at the $16^{\text {th }}$

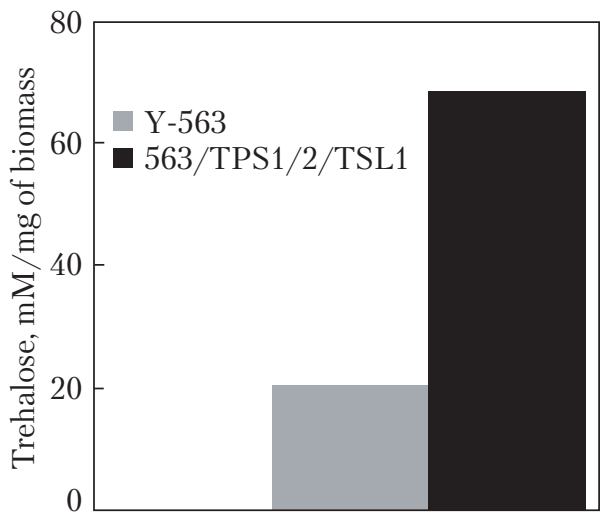

Fig. 5. Intracellular trehalose content (mM/mg) of cellular biomass for the Y-563 strain and its derivative recombinant strain 563/TPS1/2/TSL1 with the overexpression of TPS1, TPS2, and TSL1 genes

hour of fermentation. The highest production of ethanol in the studied strains is also observed at the $16^{\text {th }}$ hour of fermentation (Fig. 6). Ethanol production by $563 / \mathrm{TPS} 1 / 2 / \mathrm{TSL} 1$ strain reaches $40 \mathrm{~g} / \mathrm{L}$, whereas the parental strain Y-563 produces only up to $30 \mathrm{~g} / \mathrm{L}$ ethanol. Therefore, an increase in ethanol production makes up 33\% for the recombinant strain during high-temperature fermentation (at $40{ }^{\circ} \mathrm{C}$ ).

The obtained glycerol and trehalose overproducing strains are tested to estimate their resistance to various stresses.

To check the strains resistance to high osmotic pressure, cell suspensions of the corresponding yeast strains with optical densities of 1.0, 0.1, 10 ${ }^{-2}$, $10^{-3}, 10^{-4}$ (wave length of $600 \mathrm{~nm}$ ) are prepared; then $5 \mu \mathrm{L}$ suspension is plated onto YPD medium
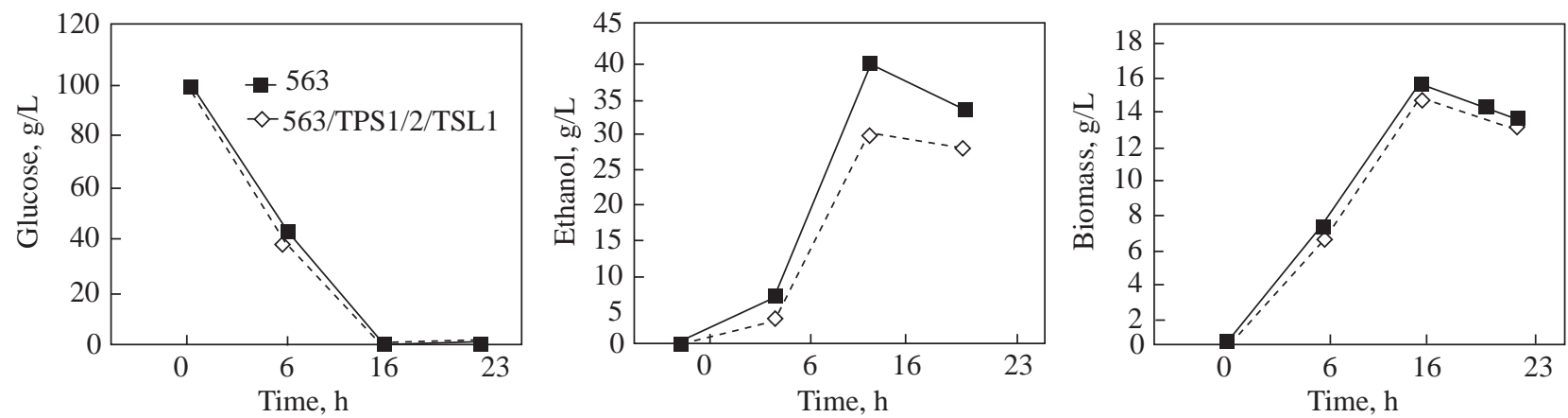

Fig. 6. Kinetics of glucose consumption, biomass accumulation, and ethanol production (g/L) by Y-563 and 563/TPS1/2/TSL1 strains during fermentation in $1 \mathrm{~L}$ fermenter in YPD medium at a stirring rate of $200 \mathrm{rpm}$, a temperature of $40{ }^{\circ} \mathrm{C}$ and $\mathrm{pH}=5.5$ 


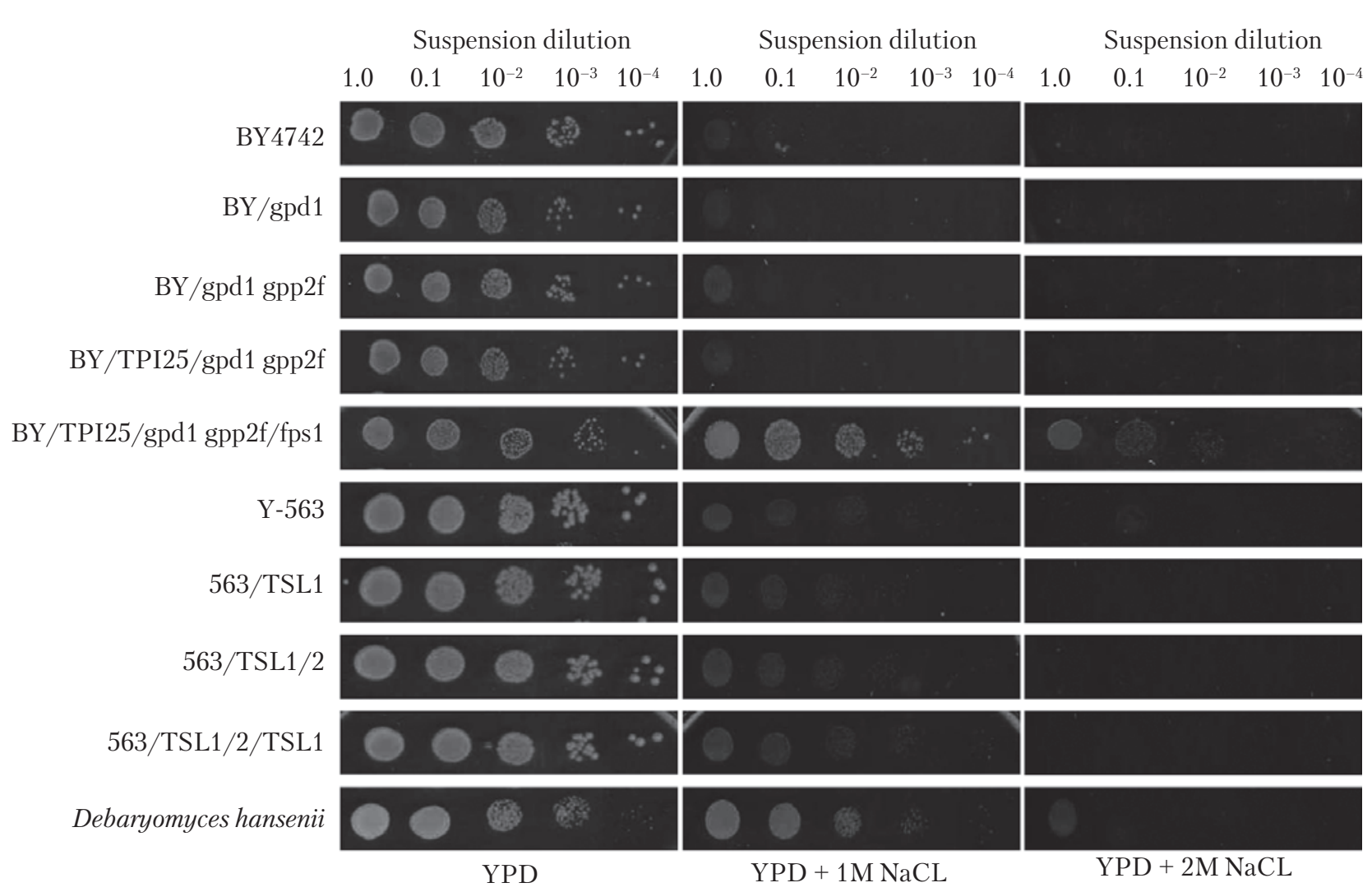

Fig. 7. Growth of studied recombinant $S$. cerevisiae strains on the media with different salt concentrations (1M or $2 \mathrm{M} \mathrm{NaCl})$

and YPD with $1 \mathrm{M} \mathrm{NaCl}$ or $2 \mathrm{M} \mathrm{NaCl}$ added. For comparison, cell suspension of osmotolerant yeast Debaryomyces hansenii is used. Strain BY/ TPI25/gpd1gpp2f/fps1 with the highest level of glycerol synthesis has been shown to have the highest osmotolerance, even higher than in D. hansenii (Fig. 7).

In order to check the recombinant strains resistance to freeze-thaw, cells suspensions with optical densities 2.0, 1.0, and 0.5 are prepared and frozen at $-20^{\circ} \mathrm{C}$ for 72 hours. To estimate the amount of living cells, the suspensions are diluted before and after freezing, plated onto the YPD medium and incubated for $2-3$ days. The yeast colonies obtained after incubation are analyzed. The percentage of cells survived is expressed as the amount of colonies obtained on the plates from suspension after freezing, divided by the amount of colonies obtained on the plates from suspension before freezing and multiplied by 100 .
Fig. 8 features the averaged result of three individual experiments.

Fig. 8 shows that strains BY/TPI25/gpd1gpp2f, 563/TSL1, 563/TPS1/2, and 563/TPS1/2/ TSL1 possess higher resistance to freeze-thaw in comparison with the respective parental strains.

The recombinant strains resistance to desiccation are calculated in similarly, i.e. by counting living cells before and after freeze desiccation in Cryo Dryer. Unfortunately, the studied recombinant strains do not show higher resistance to freeze desiccation than the parental strains (no data are shown).

The experiments with the recombinant strain 563/TPS1/2/TSL1 and parental strain Y-563 in conditions close to industrial processing are performed using the facilities of partner ENZYM COMPANY PJSC (Lviv).

The recombinant strain ability to grow and to ferment is tested using a pilot small-scale fer- 

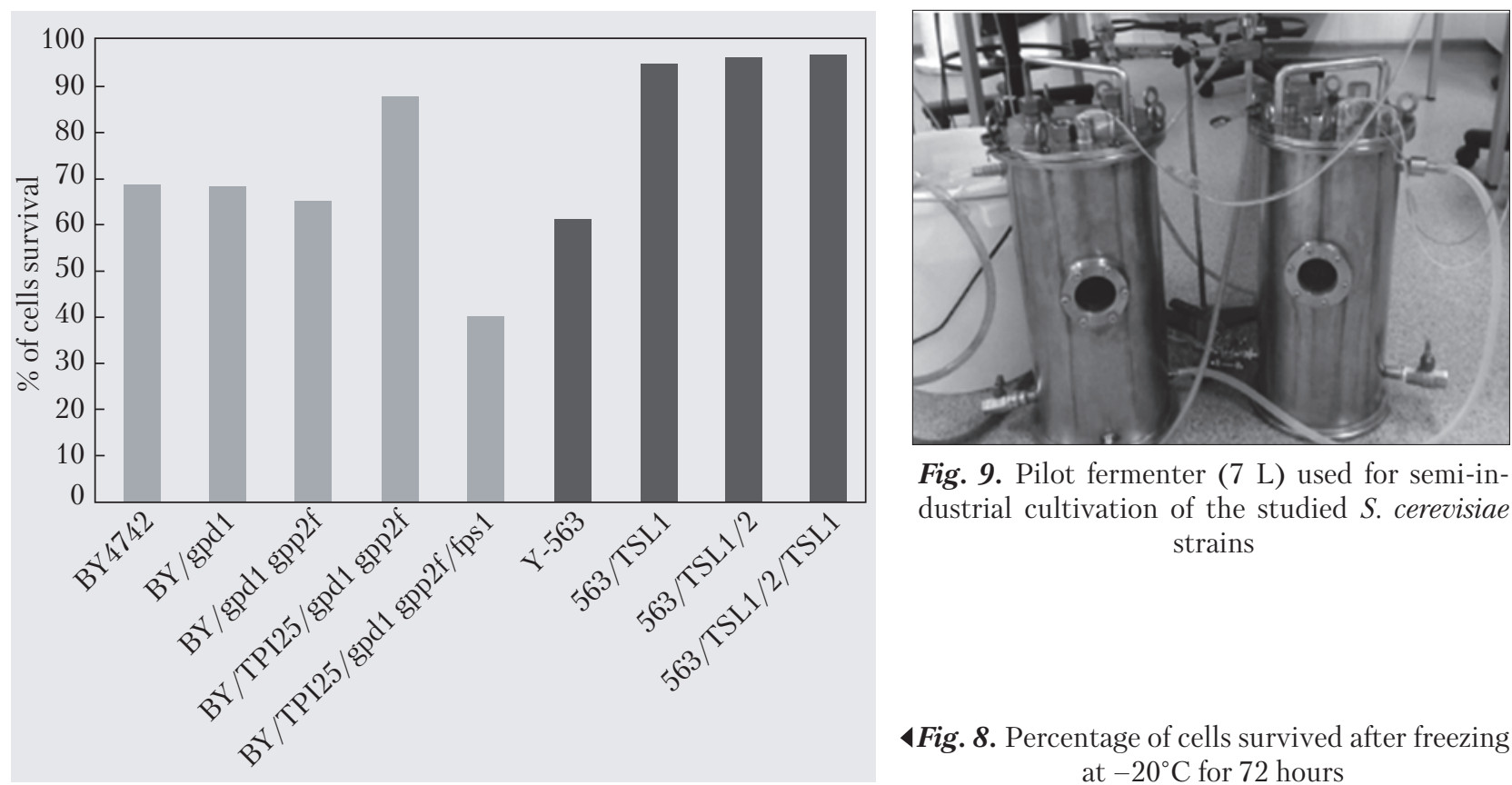

Fig. 9. Pilot fermenter (7 L) used for semi-industrial cultivation of the studied $S$. cerevisiae strains

4Fig. 8. Percentage of cells survived after freezing at $-20^{\circ} \mathrm{C}$ for 72 hours

menter (Fig. 9) with a total volume of $7 \mathrm{~L}$, filled with $4 \mathrm{~L}$ industrially-used medium with molasses, for 16 hours with sterile air aeration (at a purging rate of $10 \mathrm{~L} / \mathrm{min}$ ). The incubation temperature is $30{ }^{\circ} \mathrm{C}$. The medium contains as follows: tap water; $10 \%$ molassess as sugars source; $0.5 \%$ ammonia water as nitrogen source; $0.3 \%$ $\mathrm{KH}_{2} \mathrm{PO}_{4}$ as phosphorous source; $0.1 \% \mathrm{Na}_{2} \mathrm{SO}_{4}$ as sulfur source, antifoam solution to prevent excessive foam formation and leakage of the culture medium through the valve of the fermenter. The microelements are introduced to the medium by adding the following salts: $\mathrm{MgSO}_{4}-0.5 \mathrm{~g} / \mathrm{L}$; $\mathrm{ZnSO}_{4}-0.05 \mathrm{~g} / \mathrm{L}$; and $\mathrm{CuSO}_{4}-0.01 \mathrm{~g} / \mathrm{L}$. The medium is sterilized at a temperature of $121^{\circ} \mathrm{C}$ and a pressure of 1 atmosphere, for $30 \mathrm{~min}$. Vitamin mix including biotin and vitamins B1, B5, B6 is added after the sterilization.
The Y-563 and 563/TPS1/2/TSL1 strain biomass obtained after incubation in the fermenter is used for determination of some yeast properties important for bread baking, in particular, productivity (ethanol production in $\mathrm{g} / \mathrm{L}$ ), humidity in $\%$, stability at $35{ }^{\circ} \mathrm{C}$, and lifting force during the kneading of lean and sweet dough (Table). The lean dough contains high-grade flour, $2.5 \%$ saline solution, and yeasts. The sweet dough is prepared similarly to the lean one, but additionally contains 15\% sugar and margarine, which create a medium with a high osmotic pressure.

The recombinant strain with high intracellular trehalose content (563/TPS1/2/TSL1) has been shown to longer keep its fermentation activity at $35^{\circ} \mathrm{C}$ in comparison with the initial strain. Although the recombinant strain ferments the lean dough worse than the initial strain, it better fer-

Properties of Strains Y-563 and 563/TPS1/2/TSL1 Biomass Produced in Semi-Industrial Conditions in Pilot Fermenter

\begin{tabular}{|l|c|c|c|c|c|}
\hline \multicolumn{1}{|c|}{ Strain } & $\begin{array}{c}\text { Productivity, } \\
\mathrm{g} / \text { L ethanol }\end{array}$ & $\begin{array}{c}\text { Humidity, } \\
\%\end{array}$ & $\begin{array}{c}\text { Lifting force (lean dough) } \\
\mathrm{CO}_{2} \mathrm{ml} / \mathrm{g} \text { dough }\end{array}$ & $\begin{array}{c}\text { Lifting force (sweet dough) } \\
\mathrm{CO}_{2} \mathrm{ml} / \mathrm{g} \text { dough }\end{array}$ & $\begin{array}{c}\text { Stability at 35 }{ }^{\circ} \mathrm{C}, \\
\text { hours }\end{array}$ \\
\hline Y-536 & 53 & 75.2 & 339 & 331 & 94 \\
563/TPS1/2/TSL1 & 52 & 74.6 & 295 & 375 & 100 \\
\hline
\end{tabular}


ments sugar in the sweet dough, therefore it is more resistant to high osmotic pressure than the Y-563 strain.

\section{CONCLUSIONS}

The $S$. cerevisiae recombinant strains with higher glycerol production (up to $19 \mathrm{~g} / \mathrm{L}$ ) have been constructed based on BY4742. The industrial ethanol-producing strain Y-563 has been used as parental one for construction of recombinant strains with up to 3.3-fold increase in the intracellular trehalose level. The resistance of obtained recombinant strains to different stress factors has been evaluated. The strain BY/TPI25/ gpd1gpp2f/fps1 has shown the highest osmotolerance. The strains BY/TPI25/gpd1gpp2f, 563/ TSL1, 563/TPS1/2, and 563/TPS1/2/TSL1 have shown higher viability after freeze-thaw as compared with the corresponding parental strains. The recombinant strain 563/TPS1/2/ TSL1 with a high trehalose content and the cor- responding initial strain Y-563 have been grown in the commercial medium in $7 \mathrm{~L}$ pilot fermenter and tested. The recombinant strain cells have been established to have higher activity during fermentation of sugar in the sweet dough and to longer keep their stability at $35^{\circ} \mathrm{C}$. Therefore, this newly constructed strain can be used for commercial production of baker's yeast having extended shelf life and better suitability for sweet dough leavening. Also, this strain can be used as a platform for implementing other authors' offerings (for example, for metabolic engineering that increases glycerol production) and for obtaining $S$. cerevisiae with higher robustness.

Acknowlegement. This research is supported by the National Academy of Sciences of Ukraine (Grant 27-17) and our partners from ENZYM COMPANY PJSC (Lviv). The authors appreciate very much the contribution of Yuri Pynyaha and Olena Krasozska from ENZYM COMPANY PJSC.

\section{REFERENCES}

1. Ahmadpour, D., Geijer, C., Tamas, M. J., Lindkvist-Petersson, K., Hohmann, S. (2014). Yeast reveals unexpected roles and regulatory features of aquaporins and aquaglyceroporins. Biochim. Biophys. Acta, 1840(5), 1482-1491. doi: 10.1016/j. bbagen.2013.09.027

2. Albertyn, J., Hohmann, S., Thevelein, J. M., Prior, B. A. (1994). GPD1, which encodes glycerol-3-phosphate dehydrogenase, is essential for growth under osmotic stress in Saccharomyces cerevisiae, and its expression is regulated by the highosmolarity glycerol response pathway. Mol. Cell Biol., 14(6), 4135-4144.

3. Ando, A., Nakamura, T., Murata, Y., Takagi, H., Shima, J. (2007). Identification and classification of genes required for tolerance to freeze-thaw stress revealed by genome-wide screening of Saccharomyces cerevisiae deletion strains. FEMS Yeast Res., 7(2), 244-253. doi: 10.1111/j.1567-1364. 2006.00162.x

4. Attfield, P. V. (1997). Stress tolerance: the key to effective strains of industrial baker's yeast. Nat. Biotechnol., 15(13), 1351-1357. doi: 10.1038/nbt1297-1351

5. Blomberg, A., Adler, L. (1989). Roles of glycerol and glycerol-3-phosphate dehydrogenase (NAD+) in acquired osmotolerance of Saccharomyces cerevisiae.J. Bacteriol., 171(2), 1087-1092.

6. Blomberg, A., Adler, L. (1992). Physiology of osmotolerance in fungi. Adv. Microb. Physiol., 33, 145-212.

7. Brown, A. D. (1978). Compatible solutes and extreme water stress in eukaryotic micro-organisms. Adv. Microb. Physiol., 17, 181-242.

8. Byun, S., Lee, E., Lee, K. W. (2017). Therapeutic Implications of Autophagy Inducers in Immunological Disorders, Infection, and Cancer. Int.J. Mol. Sci., 18(9), E1959. doi: 10.3390/ijms18091959

9. Crowe, J. H. (2007). Trehalose as a "chemical chaperone": fact and fantasy. Adv. Exp. Med. Biol., 594, 143-158. doi: 10.1007/978-0-387-39975-1_13

10. Eriksson, P., Andre, L., Ansell, R., Blomberg, A., Adler, L. (1995). Cloning and characterization of GPD2, a second gene encoding sn-glycerol 3-phosphate dehydrogenase $\left(\mathrm{NAD}^{+}\right)$in Saccharomyces cerevisiae, and its comparison with GPD1. Mol. Microbiol., 17(1), 95-107.

11. Francois, J., Parrou, J. L. (2001). Reserve carbohydrates metabolism in the yeast Saccharomyces cerevisiae. FEMS Microbiol. Rev., 25(1), 125-145.

12. Gonchar, M. V., Maidan, M. M., Pavlishko, H. M., Sibirny, A. A. (2001). A new oxidase-peroxidase kit for ethanol assays in alcoholic beverages. Food Technol. Biotechnol., 39, 37-42. 
13. Grant, W. D. (2004). Life at low water activity. Philos. Trans. R. Soc. Lond. B. Biol. Sci., 359, 1249-1266; discussion $1266-1247$.

14. Guo, Z. P., Zhang, L., Ding, Z. Y., Shi, G. Y. (2011). Minimization of glycerol synthesis in industrial ethanol yeast without influencing its fermentation performance. Metab. Eng., 13(1), 49-59. doi: 10.1016/j.ymben.2010.11.003

15. Hohmann, S. (2002). Osmotic stress signaling and osmoadaptation in yeasts. Microbiol. Mol. Biol. Rev., 66(2), $300-372$.

16. Ishchuk, O. P., Voronovsky, A. Y., Abbas, C. A., Sibirny, A. A. (2009). Construction of Hansenula polymorpha strains with improved thermotolerance. Biotechnol. Bioeng., 104(5), 911-919. doi: 10.1002/bit.22457

17. Jung, Y. J., Park, H. D. (2005). Antisense-mediated inhibition of acid trehalase (ATH1) gene expression promotes ethanol fermentation and tolerance in Saccharomyces cerevisiae. Biotechnol. Lett., 27(23-24), 1855-1859. doi: 10.1007/ s10529-005-3910-3

18. Kawai, S., Hashimoto, W., Murata, K. (2010). Transformation of Saccharomyces cerevisiae and other fungi: methods and possible underlying mechanism. Bioeng. Bugs., 1(6), 395-403. doi: 10.4161/bbug.1.6.13257

19. Kim, J., Alizadeh, P., Harding, T., Hefner-Gravink, A., Klionsky, D. J. (1996). Disruption of the yeast ATH1 gene confers better survival after dehydration, freezing, and ethanol shock: potential commercial applications. Appl. Environ. Microbiol., 62(5), 1563-1569.

20. Larsson, K., Ansell, R., Eriksson, P., Adler, L. (1993). A gene encoding sn-glycerol 3-phosphate dehydrogenase (NAD $)$ complements an osmosensitive mutant of Saccharomyces cerevisiae. Mol. Microbiol., 10(5), 1101-1111.

21. Lee, Y. J., Jeschke, G. R., Roelants, F. M., Thorner, J., Turk, B. E. (2012). Reciprocal phosphorylation of yeast glycerol-3-phosphate dehydrogenases in adaptation to distinct types of stress. Mol. Cell Biol., 32(22), 4705-4717. doi: 10.1128/ MCB.00897-12

22. Londesborough, J., Varimo, K. (1984). Characterization of two trehalases in baker's yeast. Biochem.J., 219(2), 511-518.

23. Luyten, K., Albertyn, J., Skibbe, W. F., Prior, B. A., Ramos, J., Thevelein, J. M., Hohmann, S. (1995). Fps1, a yeast member of the MIP family of channel proteins, is a facilitator for glycerol uptake and efflux and is inactive under osmotic stress. EMBOJ., 14(7), 1360-1371.

24. Luzhetskyi, T., Semkiv, M., Dmytruk, K., Sibirny, A. (2015). Improving Thermotolerance of Saccharomyces cerevisiae Industrial Yeast Strain via Derepression of Genes of Trehalose Synthesis. In A. Sibirny, D. Fedorovych, M. Gonchar \& D. Grabek-Lejko (Eds.), Living Organisms and Bioanalytical Approaches for Detoxification and Monitoring of Toxic Compounds: Monograph. (pp. 259-268). Rzeszow: University of Rzeszow.

25. Meynial Salles, I., Forchhammer, N., Croux, C., Girbal, L., Soucaille, P. (2007). Evolution of a Saccharomyces cerevisiae metabolic pathway in Escherichia coli. Metab. Eng., 9(2), 152-159. doi: 10.1016/j.ymben.2006.09.002

26. Norbeck, J., Pahlman, A. K., Akhtar, N., Blomberg, A., Adler, L. (1996). Purification and characterization of two isoenzymes of DL-glycerol-3-phosphatase from Saccharomyces cerevisiae. Identification of the corresponding GPP1 and GPP2 genes and evidence for osmotic regulation of Gpp2p expression by the osmosensing mitogen-activated protein kinase signal transduction pathway. J. Biol. Chem., 271(23), 13875-13881.

27. Nwaka, S., Mechler, B., Holzer, H. (1996). Deletion of the ATH1 gene in Saccharomyces cerevisiae prevents growth on trehalose. FEBS Lett., 386(2-3), 235-238.

28. Oliveira, A. P., Ludwig, C., Picotti, P., Kogadeeva, M., Aebersold, R., Sauer, U. (2012). Regulation of yeast central metabolism by enzyme phosphorylation. Mol. Syst. Biol., 8, 623. doi: 10.1038/msb.2012.55

29. Overkamp, K. M., Bakker, B. M., Kotter, P., Luttik, M. A., Van Dijken, J. P., Pronk, J. T. (2002). Metabolic engineering of glycerol production in Saccharomyces cerevisiae. Appl. Environ. Microbiol., 68(6), 2814-2821.

30. Pahlman, A. K., Granath, K., Ansell, R., Hohmann, S., Adler, L. (2001). The yeast glycerol 3-phosphatases Gpp1p and Gpp2p are required for glycerol biosynthesis and differentially involved in the cellular responses to osmotic, anaerobic, and oxidative stress. J. Biol. Chem., 276(5), 3555-3563. doi: 10.1074/jbc.M007164200

31. Pettersson, N., Filipsson, C., Becit, E., Brive, L., Hohmann, S. (2005). Aquaporins in yeasts and filamentous fungi. Biol. Cell., 97(7), 487-500. doi: 10.1042/BC20040144

32. Randez-Gil, F., Sanz, P., Prieto, J. A. (1999). Engineering baker's yeast: room for improvement. Trends. Biotechnol., 17(6), 237-244.

33. Remize, F., Barnavon, L., Dequin, S. (2001). Glycerol export and glycerol-3-phosphate dehydrogenase, but not glycerol phosphatase, are rate limiting for glycerol production in Saccharomyces cerevisiae. Metab. Eng., 3(4), 301-312. doi: 10.1006/mben.2001.0197

34. Semkiv, M. V., Dmytruk, K. V., Abbas, C. A., Sibirny, A. A. (2017). Metabolic engineering for high glycerol production by the anaerobic cultures of Saccharomyces cerevisiae. Appl. Microbiol. Biotechnol., 101(11), 4403-4416. doi: 10.1007/ s00253-017-8202-z 
35. Tamas, M. J., Luyten, K., Sutherland, F. C., Hernandez, A., Albertyn, J., Valadi, H., Li, H., Prior, B. A., Kilian, S. G., Ramos, J., Gustafsson, L., Thevelein, J. M., Hohmann, S. (1999). Fps1p controls the accumulation and release of the compatible solute glycerol in yeast osmoregulation. Mol. Microbiol., 31(4), 1087-1104.

36. Tapia, H., Koshland, D. E. (2014). Trehalose is a versatile and long-lived chaperone for desiccation tolerance. Curr. Biol., 24(23), 2758-2766. doi: 10.1016/j.cub.2014.10.005

37. ter Linde, J. J., Liang, H., Davis, R. W., Steensma, H. Y., van Dijken, J. P., Pronk, J. T. (1999). Genome-wide transcriptional analysis of aerobic and anaerobic chemostat cultures of Saccharomyces cerevisiae.J. Bacteriol., 181(24), 7409-7413.

38. Wiemken, A. (1990). Trehalose in yeast, stress protectant rather than reserve carbohydrate. Antonie Van Leeuwenhoek, 58(3), 209-217.

39. Yancey, P. H., Clark, M. E., Hand, S. C., Bowlus, R. D., Somero, G. N. (1982). Living with water stress: evolution of osmolyte systems. Science, 217(4566), 1214-1222.

Received 25.05.18

\author{
М.В. Семків, О.Т. Тернавська, К.В. Дмитрук, А.А. Сибірний \\ Інститут біології клітини Національної академії наук України, \\ вул. Драгоманова, 14/16, Львів, 79005, Україна, \\ +380 3226 12108, +380 3226 12148, sibirny@cellbiol.lviv.ua
}

\title{
ВПЛИВ ТРЕГАЛОЗИ ТА ГЛІЦЕРИНУ НА СТІЙКІСТЬ ДО ВИСУШУВАННЯ, ЗАМОРОЖУВАННЯ-РОЗМОРОЖУВАННЯ ТА ОСМОТИЧНОГО СТРЕСУ У РЕКОМБIНАНТНИХ ШТАМIB SACCHAROMYCES CEREVISIAE
}

Вступ. Пекарські дріжджі Saccharomyces cerevisiae використовують у виробництві хлібобулочних виробів, харчових та кормових добавок, алкогольній ферментації тощо. У біотехнологічних процесах клітини дріжджів зазнають дії значної кількості стресових факторів (висока концентрація цукру та етанолу, підвищена температура, висушування або заморожування тощо), що негативно впливає на їх життєздатність. Дріжджі володіють певними системами захисту від стресу, зокрема накопичення дисахариду трегалози та продукування гліцерину.

Проблематика. Посилення дії захисних систем дріжджів шляхом збільшення концентрації гліцерину або трегалози може надати більшої стресостійкості штамам $S$. cerevisiae.

Мета. Конструювання рекомбінантних штамів S. cerevisiae з підвищеним рівнем накопичення трегалози або продукування гліцерину та оцінка стійкості отриманих штамів до низки стресових факторів.

Матеріали й методи. Трансформацію S. сеrevisiae здійснювали методом Li-Ac-PEG. Алкогольну ферментацію здійснювали при температурі $30{ }^{\circ} \mathrm{C}$ при перемішуванні зі швидкістю 120 об/хв.

Результати. На основі штаму S. cerevisiae BY4742 було сконструйовано рекомбінантні штами з підвищеним рівнем продукування гліцерину (до 19 г/л). На основі промислового штаму Y-563 як продуцента етанолу було сконструйовано рекомбінантні штами з підвищеним в 3,3 рази внутрішньоклітинним вмістом трегалози. Визначено резистентність отриманих рекомбінантних штамів до різних стресових факторів. Штам BY/TPI25/gpd1gpp2f/fps1 3 найвищим рівнем продукції гліцерину виявляв найвищу осмотолерантність. Штами BY/TPI25/gpd1gpp2f, 563/ TSL1, 563/TPS1/2 та 563/TPS1/2/TSL1 характеризувалися підвищеною життєздатністю після заморожуваннярозморожування порівняно з батьківськими штамами, проте не виявляли вищої стійкості до висушування. Рекомбінантний штам 563/TPS1/2/TSL1 з високим вмістом трегалози виявляв вищу активність при зброджуванні цукру в здобному тісті та довше зберігав життєвість при $35^{\circ} \mathrm{C}$, порівняно з батьківським штамом Y-563.

Висновки. Сконструйовані рекомбінантні штами S. cerevisiae можуть бути використані в промислових процесах, що супроводжуються заморожуванням-розморожуванням клітин дріжджів або високим осмотичним тиском у культуральному середовищі. Хлібопекарські дріжджі з підвищеним внутрішньоклітинним вмістом трегалози мають більш тривалий термін зберігання.

Ключові слова: пекарські дріжджі, трегалоза, гліцерол, заморожування-розморожування, висушування, осмотолерантність. 


\author{
М.В. Семкив, О.Т. Тернавская, К.В. Дмитрук, А.А. Сибирный \\ Институт биологии клетки Национальной академии наук Украины, \\ ул. Драгоманова, 14/16, Львов, 79005, Украина, \\ +38032 26 12108, +380 3226 12148, sibirny@cellbiol.lviv.ua

\section{ВЛИЯНИЕ ТРЕГАЛОЗЫ И ГЛИЦЕРИНА НА УСТОЙЧИВОСТЬ К ВЫСУШИВАНИЮ, ЗАМОРАЖИВАНИЮ-РАЗМОРАЖИВАНИЮ И ОСМОТИЧЕСКОМУ СТРЕССУ У РЕКОМБИНАНТНЫХ ШТАММОВ SACCHAROMYCES CEREVISIAE}

Введение. Пекарские дрожжи Saccharomyces cerevisiae используют при изготовлении хлебобулочных изделий, пищевых и кормовых добавок, алкогольной ферментации и т.д. В биотехнологических процессах клетки дрожжей подвергаются действию значительного количества стрессовых факторов (высокая концентрация сахара и этанола, повышенная температура, высушивание или замораживание и прочие), что отрицательно влияет на их жизнеспособность. Дрожжи владеют определенными системами защиты от стресса, в частности накопление дисахарида трегалозы и продуцирование глицерина.

Проблематика. Усиление действия защитных систем дрожжей путем увеличения концентрации глицерина или трегалозы может способствовать большей стрессоустойчивости штаммов S. cerevisiae.

Цель. Конструирование рекомбинантных штаммов $S$. cerevisiae с повышенным уровнем накопления или продуцирования глицерина, а также оценка устойчивости полученных штаммов к ряду стрессовых факторов.

Материалы и методы. Трансформацию S. cerevisiae выполняли методом Li-Ac-PEG. Алкогольную ферментацию проводили при температуре $30{ }^{\circ} \mathrm{C}$ при перемешивании со скоростью 120 об/мин.

Результаты. На основании штамма S. cerezisiae BY4742 были сконструированы рекомбинантные штаммы с повышенным уровнем продуцирования глицерина (до 19 г/л). На основании промышленного штамма Y-563 как продуцента этанола было сконструировано рекомбинантные штаммы с повышенным в 3,3 раза внутриклеточным содержанием трегалозы. Определено резистентность полученных рекомбинантных штаммов к различным стрессовым факторам. Штамм BY/TPI25/gpd1gpp2f/fps1 с наивысшим уровнем продуцирования глицерина, имел наивысшую осмотолерантность. Штаммы BY/TPI25/gpd1gpp2f, 563/TSL1, 563/TPS1/2 и 563/TPS1/2/TSL1 имели повышенную жизнеспособность после замораживания-размораживания по сравнению с родительскими штаммами, но не проявляли большей стойкости к высушиванию. Рекомбинантный штамм 563/TPS1/2/TSL1 с высоким содержанием трегалозы проявлял более высокую активность при брожении сахара в сдобном тесте и дольше сохранял жизнеспособность при $35^{\circ} \mathrm{C}$, по сравнению с родительским штаммом Y-563.

Выводы. Сконструированные рекомбинантные штаммы $S$. cerevisiae могут использоваться в промышленных процессах, которые сопровождаются замораживанием-размораживанием клеток дрожжей или высоким осмотическим давлением в культуральной среде. Хлебопекарские дрожжи с повышенным внутриклеточным содержанием трегалозы имеют более длительный срок хранения.

Ключевые слова: пекарские дрожжи, трегалоза, глицерол, замораживание-размораживание, высушивание, осмотолерантность. 